\title{
LIFE CYCLE COST ANALYSIS AND LIFE \\ CYCLE ASSESSMENT FOR ROAD PAVEMENT \\ MATERIALS AND RECONSTRUCTION \\ TECHNOLOGIES
}

\section{ARTURS RIEKSTINS ${ }^{*}$, VIKTORS HARITONOVS ${ }^{2}$, VERNERS STRAUPE ${ }^{3}$ \\ ${ }^{1-3}$ Dept of Roads and Bridges, Riga Technical University, Riga, Latvia \\ ${ }^{1}$ SJSC Latvian State Roads, Riga, Latvia \\ ${ }^{3}$ SC “Celuprojekts", Riga, Latvia}

Received 27 February 2020; accepted 19 August 2020

\begin{abstract}
With limited funding and a desire to reduce environmental impact, there is a lot of pressure on road Authorities to develop decision making policy to manage better, build and maintain the road network sustainability. One of the solutions is to use various life cycle analyses. Numerous tools are available for different analyses, but they usually evaluate the construction from one perspective (economical, environmental, or social). Therefore, it was decided to develop a tool, which combines economic (Life Cycle Cost Analysis) and environmental (Life Cycle Assessment) analyses. The given study presents the methodology of the self-developed calculation program, which compare fulldepth road constructions. Paper also shows shortcomings when calculation does not include all life cycle processes. In this study, five different road pavement
\end{abstract}

* Corresponding author. E-mail: riekstins.arturs@gmail.com

Arturs RIEKSTINS (ORCID ID 0000-0002-5786-1333)

Viktors HARITONOVS (ORCID ID 0000-0003-3119-2677)

Verners STRAUPE (ORCID ID 0000-0002-1877-8190)

Copyright (C) 2020 The Author(s). Published by RTU Press

This is an Open Access article distributed under the terms of the Creative Commons Attribution License (http://creativecommons.org/licenses/by/4.0/), which permits unrestricted use,

distribution, and reproduction in any medium, provided the original author and source are credited. 
constructions and reconstruction plans were compared. The difference between these pavements was in the layer thickness, recycled asphalt content in asphalt layers and the use of cement or fly ash in the road base layers. The results showed that the full depth reclamation technology in comparison to the fulldepth removal and replacement reduce emissions by $60 \%$ and costs by $50 \%$.

Keywords: cold-in-place recycling, deterministic and probabilistic approach, fly ash, Life Cycle Cost Analysis, Life Cycle Impact Assessment, sustainable decision policy.

\section{Introduction}

At the time when funding for the maintenance of the road network tends to decrease road administrations are looking at ways to improve existing decision-making methodology to build and maintain the road network in a sustainable manner. A simplified definition of sustainability is to meet the needs of the present without compromising the ability of future generations to meet their needs (Brundtland Commission, 1987). The main prerequisites are to build and maintain roads as cheap as possible without causing environmental pollution or endangering human health. Consequently, it is necessary to reconcile the various requirements with the feasibility and to select the materials, technologies, and strategies that are best to meet conditions in the long term.

Various analyses are used to evaluate different materials, technologies, and strategies. The purpose of these analyses is to evaluate the long-term results. The three most used analyses are Life Cycle Cost Analysis (LCCA), Life Cycle Assessment (LCA), Social Impact Assessment (SIA). LCCA and LCA are very often used because the results are easier to measure. On the other hand, SIA is rarely used, and, for most cases, mainly just as a recommendation or normative (Shukla \& Jani, 2018).

LCCA is widely used to evaluate the long-term costs of construction technologies, materials and restoration plans (Babashamsi, Yusoff, Ceylan, Nor, \& Jenatabadi, 2016; Chen, Yang, \& Lee, 2019; Li, Xiao, Zhang, \& Amirkhanian, 2019). Several economic variables are defined - discount rate, salvage value and present value - to calculate and precisely compare the costs. It is possible to analyse two sides road owner (authority) and user (Babashamsi, Yusoff, Ceylan, Nor, \& Jenatabadi, 2016). Mostly it is done from the road owner side where planning, construction, design, maintenance, and rehabilitation costs are calculated (Babashamsi, Yusoff, Ceylan, Nor, \& Jenatabadi, 2016). The other part is a road user where all information about delay costs, vehicle operating costs and accident costs have been collected. Various
Life Cycle Cost Analysis and Life Cycle Assessment for Road Pavement Materials and Reconstruction Technologies 
methodologies and calculation programs are widely available for the LCCA, and Li, Xiao, Zhang, \& Amirkhanian (2019) made a detailed comparison.

Completely different results are possible to get from LCA that enable to assess the environmental impact of different materials, technologies and strategies (Santero, Masanet, \& Horvath, 2010). The popularity of LCA has overgrown in the $21^{\text {st }}$ century due to enormous concerns about human-made climate change. Steps and guidelines for performing the analysis are described in ISO 14040:2006/AMD 1:2020 Environmental Management - Life Cycle Assessment - Principles and Framework Amendment 1. In this standard, the LCA framework is divided into four stages - goal and scope definition; Life Cycle Inventory (LCI), Life Cycle Impact Assessment (LCIA), and interpretation as the main units of the LCI are GHG $\left(\mathrm{CO}_{2}, \mathrm{NO}_{2}\right)$, non-renewable resources (oil, mineral materials), materials (raw materials, recycled asphalt, recycled road pavement). Performing an analysis highlights the advantages of using technologies such as WARMIX (Ma, Zhang, Zhao, \& Wu, 2019), thin asphalt layers (Riekstins, Haritonovs, Abolins, Straupe, \& Tihonovs, 2019), reclaimed asphalt (Chen \& Wang, 2018). Likewise, the use of various by-products in road construction as ash (Vestin, Arm, Nordmark, Lagerkvist, Hallgren, \& Lind, 2012), cement bypass dust (Ramadan \& Ashteyat, 2009), red mud (Lima, Thives, \& Haritonovs, 2017). Santos, Thyagarajan, Keijzer, Flores, \& Flintsch (2017) have made a detailed comparison between different LCA calculation programs that are used in Europe and the United States of America.

Both LCCA and LCA are mutually compatible because the processes and actions where data are taken are almost the same. The main benefits of performing both analyses together are - time-consuming, and results for LCCA and LCA are better comparable. Santos, Thyagarajan, Keijzer, Flores, \& Flintsch (2017) identified that with different tools, it is possible to acquire different results. The use of different frameworks and databases are the main reasons for inaccuracy. Only a few studies have looked at the possibility to make both the most popular analyses LCCA and LCA together (Li, Xiao, Zhang, \& Amirkhanian, 2019; Santos, Flintsch, \& Ferreira, 2017).

This research shows results from the calculation program development Level 2 (out of 3) where economic and environmental analyses were made-more details of differences between calculation development levels are shown in Table 1. Results obtained in the previous paper showed that wearing course of thin asphalt (BBTM) has great potential because of reduced thickness (less material is used). For the development Level 3, the road user part will be included, and results will be presented in the next publication. In this study, five different 
Table 1. Summary of calculation development progress

\begin{tabular}{|c|c|c|c|}
\hline \multirow{3}{*}{ Position } & Level 1 & Level 2 & Level 3 \\
\hline & \multicolumn{3}{|c|}{ Publication } \\
\hline & $\begin{array}{c}\text { Riekstins, Haritonovs, } \\
\text { Abolins, Straupe, } \\
\text { \& Tihonovs, } 2019\end{array}$ & $\begin{array}{c}\text { This } \\
\text { paper }\end{array}$ & $\begin{array}{c}\text { In } \\
\text { progress }\end{array}$ \\
\hline Life Cycle & + & + & + \\
\hline \multicolumn{4}{|l|}{ Cost Analysis } \\
\hline Life Cycle & - & + & + \\
\hline \multicolumn{4}{|l|}{ Assessment } \\
\hline Full-depth & - & + & + \\
\hline pavement & (asphalt layers) & & \\
\hline Stages & Partly production & Partly production & Cradle \\
\hline included & and use stages; & and use stages; & to grave \\
\hline in the & Construction stage & Construction & \\
\hline calculation & & stage & \\
\hline Salvage value & - & + & + \\
\hline User costs & - & - & + \\
\hline
\end{tabular}

road pavement constructions were compared. These pavements differ with reconstruction method (removal-replacement and full-depth reclamation), the thickness of the layers, the use of recycled materials and the use of by-products. Two mathematics modules - deterministic and probabilistic were used to make an analysis.

\section{Objective}

The main objective of this paper is to investigate whether it is accurate to compare various pavement constructions and rehabilitation practises from the economical (LCCA) and environmental (LCA) standpoint if raw material extraction processes are not taken in an account. For this purpose, different materials, building technologies and rehabilitation strategies were compared.

\section{Background of analysis}

In the early stage of research, available calculation tools were reviewed. There are many different programmes and tools in the market. These tools/programmes are divided into two groups - the ones that are being used in a wide range of areas and the ones that are used in
Life Cycle Cost Analysis and Life Cycle Assessment for Road Pavement Materials and Reconstruction Technologies 
Table 2. Limits on the use of different tools

\begin{tabular}{|c|c|c|c|c|}
\hline \multirow{2}{*}{ Type of analysis } & \multicolumn{2}{|c|}{ Life Cycle Assessment } & \multicolumn{2}{|c|}{ Life Cycle Cost Analysis } \\
\hline & Deterministic & Probabilistic & Deterministic & Probabilistic \\
\hline Owner & PaLATE-2.0 & SimaPro & PaLATE-2.0 & RealCost-2.5 \\
\hline \multirow[t]{2}{*}{ (authority) } & SimaPro & & RealCost-2.5 & \\
\hline & OneClickLCA & & OneClickLCA & \\
\hline User & not calculated & not calculated & RealCost-2.5 & RealCost-2.5 \\
\hline
\end{tabular}

one specific area. Two most popular existing tools from every group were investigated. SimaPro and OneClickLCA are tools that are used in a wide range of areas, but the PaLATE-2.0 and RealCost-2.5 are tools that were made for comparison of road constructions. Table 2 summarizes the fields covered by these calculation programs. These tools fulfil only in certain areas. Therefore, a decision for calculation tool was made. This disadvantage, as well as the aim to implement available data from existing construction practice in Latvia and to increase package of theoretical probability distributions (e.g. exponential and Weibull distribution), led to the decision of creating a tool in Excel and VBA (Visual Basic for Applications). The combined LCA and LCCA calculation seems logical since the processes, which are summed up, overlap in both analyses.

The well-known analyses, LCCA and LCA, were used to develop a methodology for integrated life cycle analysis. The application of both methods is similar because their results are obtained by summing up the related values of activities and processes. For LCCA these are costs but for LCA - emissions and the number of materials. As the most appropriate analysis period of 40 years was chosen.

\subsection{Life Cycle Assessment}

The Life Cycle Assessment (LCA) was used to measure environmental impacts between alternatives. Environmental impacts are directly related to the materials, technologies, and rehabilitation strategies. The environmental impacts, which are generated from the road users, were not included in this study. The ISO 14040:2006/ AMD 1:2020 Environmental Management - Life Cycle Assessment Principles and Framework - Amendment 1 standard was used as the guidelines for LCA. As reported by the European Parliament, $81 \%$ of all Greenhouse Gases (GHGs) produced in different sectors worldwide, is $\mathrm{CO}_{2}$. Thus, $\mathrm{CO}_{2}$ was taken as the main measurement of environmental impacts. 


\subsubsection{Greenhouse emission from fuel}

Greenhouse Gas (GHG) was calculated based on fuel consumption (Fontaras, Zacharof, \& Ciuffo, 2017). Every equipment, which is used for transportation, production, or construction in the material databases, has average fuel consumption based on local construction company experience. Unfortunately, manufacturers do not share information about how much emissions are produced by different types of equipment at some level of productivity. There is a good sign from the European Union because a simulation tool for heavy-duty vehicles has been made. That data is going to be available in the future. In this study, simple formulas were used to calculate fuel consumption into emissions. Table 3 shows the carbon content of different fuels. Mean values were used in the calculation.

Table 3. $\mathrm{CO}_{2}$ emissions produced concerning fuel type

\begin{tabular}{ll}
\hline \multicolumn{1}{c}{ Type of fuel } & \multicolumn{1}{c}{ Kilograms of carbon dioxide, $\mathrm{CO}_{2}$} \\
\hline Diesel & $2.65-2.84$ per litre \\
Gasoline & $2.31-2.39$ per litre \\
Natural gas & 3142 per ton $\sim 0.002514$ per litre \\
Liquid petroleum gas & $1.51-1.66$ per litre \\
\hline
\end{tabular}

\subsubsection{Fumes from asphalt production}

Fumes were not measured and included in the calculations.

\subsection{Life Cycle Cost Analysis}

Life Cycle Cost Analysis (LCCA) was used to calculate economic differences between alternatives. In this research, present and future costs were calculated for five different pavements. At this stage of the developed tool, only road owner costs (ROC) were calculated. The calculation methodology for this study was based on the Federal Highway Agency (FHWA) publication LCCA in Pavement Design (Walls \& Smith, 1998). It is essential for the LCCA calculation to correctly identify and define several economic variables, which has a significant impact on the result.

\subsubsection{Discount rate}

The value of the discount rate is essential for the LCCA calculation, as it is the primary input for converting future cash flow into present prices (Demos, 2006). Future economic indicators are difficult to predict, so it is crucial to choose the right rate carefully. The typical discount rate value is $3 \%-5 \%$. For this study, $4 \%$ were used.
Life Cycle Cost Analysis and Life Cycle Assessment for Road Pavement Materials and Reconstruction Technologies 


\subsubsection{Salvage value}

Pavement may serve more than the analysis period. For example, replacement of wearing course is planned at year 37 with service life 10 years, after analyses period (40 years) this layer still contains some value. In that case, the salvage value (SV) of the last rehabilitation was calculated by using the following Eq. (1):

$$
S V=\frac{R S L}{P S L} V O I
$$

$S V$ - salvage value; $R S L$ - remaining service life; $P S L$ - predicted service life; VOI - value of investments.

Both RSL and PSL values are related to maintenance and rehabilitation plan.

\subsubsection{Present value}

Net present value (NPV) was chosen as the most appropriate economic indicator for LCCA. The total costs consist of the initial construction costs, maintenance costs, rehabilitation costs, and salvage value (Eq. (2)):

$$
N P V=I C+\sum_{k=1}^{n} M C_{k}\left[\frac{1}{(1+i)^{n_{k}}}\right]+\sum_{k=1}^{n} R C\left[\frac{1}{(1+i)^{n_{k}}}\right]-S V\left[\frac{1}{(1+i)^{n_{a}}}\right],
$$

where $N P V$ - present value; $I C$ - initial construction; $M C$ - maintenance costs; $R C$ - rehabilitation costs; $i$ - discount rate; $n$ - years; $n_{k}$ - number of years from the initial construction; $n_{a}$ - length of the analysis period in years.

\section{Methodology}

\subsection{Goal and scope of the study}

The primary purpose of this paper is to quantify and compare the life cycle economic and environmental performances of various flexible pavements. For this purpose, five alternatives were developed with different materials, constructive layers, and reconstruction plans. From the economical side, such costs were quantified workforce, materials, maintenance, fuel. From the environmental side, $\mathrm{CO}_{2}$ emissions from such processes were quantified - construction and demolition. 


\subsection{Functional unit}

The functional unit for this study was:

1) road length $-1 \mathrm{~km}$;

2) road width $-7.5 \mathrm{~m}$ and width of the road shoulder $-1.5 \mathrm{~m}$;

3) equivalent modulus of elasticity on the top of the road pavement structure - 300-400 MPa conforming to the LSR road pavement design methodology (SJSC Latvian State Roads, 2019);

4) traffic volume -3000 vpd (vehicles per day) of which $3 \%$ are trucks;

5) analysis period of 40 years.

\subsection{Boundaries}

Every road pavement has four stages of the life cycle - production stage, construction process stage, usage stage and end of life stage. Each of these stages contains information about the activities and processes that are done in the pavement life cycle. In this paper information from three stages of the life cycle were collected. Acquisition and extraction of raw materials were not considered in this paper. Table 4 presents all activities and processes that were included in the integrated LCCA and LCA calculations.
Life Cycle Cost Analysis and Life Cycle Assessment for Road Pavement Materials and Reconstruction Technologies

Table 4. Activities and processes that are considered

\begin{tabular}{|c|c|c|}
\hline $\begin{array}{c}\text { Stage } \\
\text { of pavement } \\
\text { life cycle }\end{array}$ & $\begin{array}{l}\text { Activities } \\
\text { and } \\
\text { processes }\end{array}$ & $\begin{array}{l}\text { Values } \\
\text { that were considered } \\
\text { for this study }\end{array}$ \\
\hline $\begin{array}{l}\text { Raw material } \\
\text { extraction } \\
\text { and } \\
\text { production } \\
\text { stage }\end{array}$ & $\begin{array}{l}\text { raw material extraction process; } \\
\text { aggregate crushing } \\
\text { and screening/crude oil } \\
\text { extraction; } \\
\text { transportation of raw materials; } \\
\text { manufacturing }\end{array}$ & $\begin{array}{l}\text { fuel consumption of asphalt plant; } \\
\text { emissions produced by the plant }\end{array}$ \\
\hline $\begin{array}{l}\text { Construction } \\
\text { process } \\
\text { stage } \\
\text { (initial } \\
\text { construction) }\end{array}$ & $\begin{array}{l}\text { transport of manufactured } \\
\text { materials; } \\
\text { construction and demolition; } \\
\text { transportation of old materials; } \\
\text { construction-installation process }\end{array}$ & $\begin{array}{l}\text { amount of materials; } \\
\text { quantities of equipment required; } \\
\text { fuel consumption of transport } \\
\text { and construction equipment; } \\
\text { emissions produced by the equipment; } \\
\text { costs of labour; } \\
\text { working hours; } \\
\text { costs of materials }\end{array}$ \\
\hline
\end{tabular}


Table 4. Activities and processes that are considered

\begin{tabular}{|c|c|c|}
\hline $\begin{array}{c}\text { Stage } \\
\text { of pavement } \\
\text { life cycle }\end{array}$ & $\begin{array}{l}\text { Activities } \\
\text { and } \\
\text { processes }\end{array}$ & $\begin{array}{l}\text { Values } \\
\text { that were considered } \\
\text { for this study }\end{array}$ \\
\hline Usage stage & $\begin{array}{l}\text { raw material extraction process; } \\
\text { aggregate crushing } \\
\text { and screening/crude oil } \\
\text { extraction; } \\
\text { transportation of raw materials; } \\
\text { manufacturing; } \\
\text { transport of manufactured } \\
\text { materials; } \\
\text { de-construction and demolition; } \\
\text { transportation of old materials; } \\
\text { maintenance-rehabilitation } \\
\text { process }\end{array}$ & $\begin{array}{l}\text { Maintenance: } \\
\text { based on local experience, estimated annual } \\
\text { maintenance costs per km } \\
\text { of a road (includes crack sealing } \\
\text { and patching costs) } \\
\text { Rehabilitation: } \\
\text { fuel consumption of asphalt plant; } \\
\text { emissions produced by plant; } \\
\text { the number of materials; } \\
\text { quantities of equipment required; } \\
\text { fuel consumption of transport } \\
\text { and construction equipment; } \\
\text { emissions produced by the equipment; } \\
\text { costs of labour; } \\
\text { working hours; } \\
\text { costs of materials }\end{array}$ \\
\hline $\begin{array}{l}\text { End of life } \\
\text { stage }\end{array}$ & salvage value of all pavement & salvage value of asphalt layers \\
\hline
\end{tabular}

\subsection{Construction design}

\subsubsection{Initial pavement structure}

In the case study, an existing road section was selected. Four alternatives were designed for the base scenario conforming to the LSR road pavement design methodology (SJSC Latvian State Roads, 2019). The thicknesses of the layers were designed as the values of the elastic modulus on the top layers are equivalent. All pavement types passed shear and bend tests according to design methodology.

A (base scenario) and alternatives B and C were designed in a traditional way that includes new materials for all pavement layers or in other words - removal and replacement process. A, B and C alternatives consist of five layers - drainage layer (subbase), two crushed stone layers (road base) and two asphalt layers (surfacing). Alternative B differs from A with recycled asphalt (RA) content that is $30 \%$. It was assumed that RA does not affect the performance and service life of the pavement. Recycled asphalt was taken from the existing pavement. Alternative $C$ differs from alternative A with pavement wearing course. For alternative 
C, it is BBTM of $2.5 \mathrm{~cm}$ thickness. In the case of BBTM wearing course, it is recommended to use polymer-modified bitumen. It is more expensive than the conventional ones, but it shows better long-term properties (Kragh, Nielsen, Olesen, Goubert, Vansteenkiste, de Visscher, ..., \& Karlsson, 2011) fast to build and may have good surface properties. In recent years thin
Life Cycle Cost Analysis and Life Cycle Assessment for Road Pavement Materials

and Reconstruction Technologies

Table 5. Initial pavement construction layers

\begin{tabular}{|c|c|c|c|c|c|}
\hline \multirow{2}{*}{ Layer } & $\begin{array}{c}\text { A } \\
\text { (base scenario) }\end{array}$ & B & C & D & $\mathbf{E}$ \\
\hline & \multicolumn{3}{|c|}{ Full-depth removal and replacement } & \multicolumn{2}{|c|}{ Full-depth reclamation } \\
\hline \multirow{2}{*}{$\begin{array}{l}\text { Wearing } \\
\text { course }\end{array}$} & AC 11 & & BBTM & AC 11 & \\
\hline & $70 / 100$ & $\begin{array}{l}70 / 100+ \\
\text { RA 30\% }\end{array}$ & $11 \mathrm{PMB}$ & $70 / 100$ & \\
\hline \multirow{2}{*}{$\begin{array}{l}\text { Base } \\
\text { course }\end{array}$} & AC 22 & & & & \\
\hline & $70 / 100$ & $\begin{array}{l}\text { base 0/100 + } \\
\text { RA 30\% }\end{array}$ & $\begin{array}{l}\text { base } \\
70 / 100\end{array}$ & $70 / 100$ & \\
\hline $\begin{array}{l}\text { Upper } \\
\text { road base }\end{array}$ & Crushed stones $0 / 45$ & & & $\begin{array}{l}\text { CBGM } \\
\text { (cement) }\end{array}$ & $\begin{array}{l}\text { CBGM } \\
\text { (cement + fly ash) }\end{array}$ \\
\hline $\begin{array}{l}\text { Lower } \\
\text { road base }\end{array}$ & Crushed stones $0 / 56$ & & & $\begin{array}{l}\text { Cement } \\
\text { treated base }\end{array}$ & $\begin{array}{l}\text { Cement }+ \text { fly ash } \\
\text { treated base }\end{array}$ \\
\hline $\begin{array}{l}\text { Upper } \\
\text { subbase }\end{array}$ & \multirow{2}{*}{ Drainage material } & & & \multirow{2}{*}{ Old pavement } & \\
\hline $\begin{array}{l}\text { Lower } \\
\text { subbase }\end{array}$ & & & & & \\
\hline
\end{tabular}

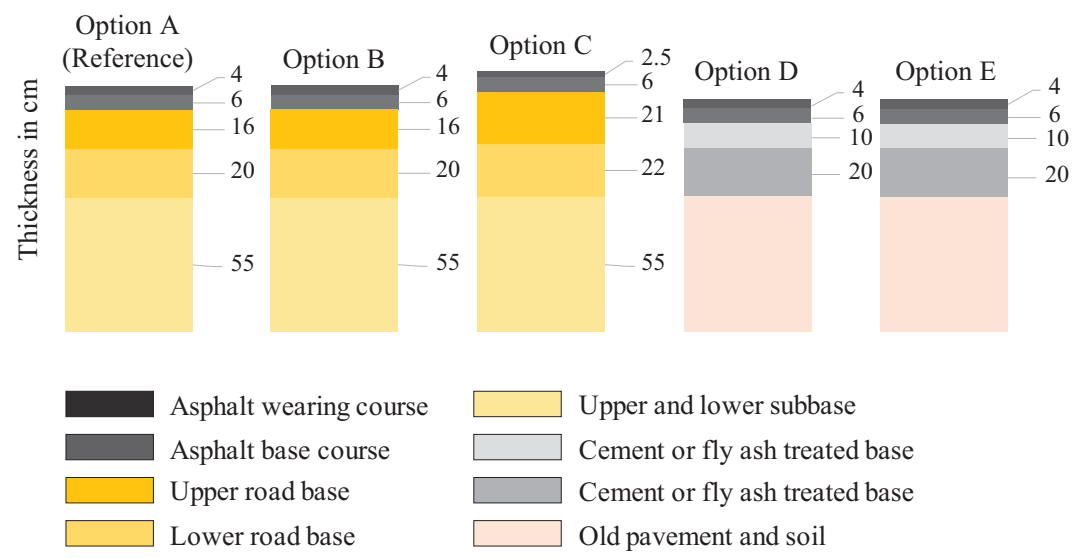

Figure 1. Different initial pavement constructions for the case study 
asphalt layers have been shown to imply reduced traffic noise levels, increased traffic safety (skid resistance and forward visibility during wet condition. Thickness reduction of wearing course was compensated by increased thickness of the crushed stone layers. Alternatives D and $\mathrm{E}$ differ from other alternatives; Full-depth reclamation was done in depth of $20 \mathrm{~cm}$. A pavement consists of four layers - a recycled old pavement layer, a cement bound granular mixture (CBGM) and two asphalt layers. The same asphalt layers as in A were designed on top of the CBGM layer. There is a single difference between alternatives D and E. Part of the cement is replaced by fly ash. Table 5 presents the information about all five initial pavement constructions, and Figure 1 - the visual layout of the pavement alternatives (layer thicknesses are given in $\mathrm{cm}$ ).

\subsubsection{Pavement maintenance and rehabilitation plan}

Based on local experience, pavement maintenance and rehabilitation (M\&R) plan was designed (Table 6). maintenance and rehabilitation

Table 6. Maintenance and rehabilitation plan of various pavements

\begin{tabular}{|c|c|c|c|c|c|c|c|c|c|}
\hline \multicolumn{2}{|c|}{ A } & \multicolumn{2}{|c|}{ B } & \multicolumn{2}{|c|}{ C } & \multicolumn{2}{|c|}{ D } & \multicolumn{2}{|c|}{ E } \\
\hline \multicolumn{6}{|c|}{ Full-depth removal and replacement } & \multicolumn{4}{|c|}{ Full-depth reclamation } \\
\hline \multirow{2}{*}{\multicolumn{2}{|c|}{$\begin{array}{c}\text { Base } \\
\text { scenario }\end{array}$}} & \multirow{2}{*}{\multicolumn{2}{|c|}{$\begin{array}{l}\text { Recycled asphalt } \\
\text { content } 30 \%\end{array}$}} & \multirow{2}{*}{\multicolumn{2}{|c|}{$\begin{array}{c}\text { BBTM } 11 \\
\text { wearing course }\end{array}$}} & \multicolumn{4}{|c|}{ Treated and built } \\
\hline & & & & & & \multicolumn{2}{|c|}{ with cement } & \multicolumn{2}{|c|}{$\begin{array}{l}\text { with cement + } \\
\text { fly ash }\end{array}$} \\
\hline IC & 0 & IC & 0 & IC & 0 & IC & 0 & IC & 0 \\
\hline W & $1-5$ & W & $1-5$ & W & $1-5$ & W & $1-5$ & W & $1-5$ \\
\hline M & $6-11$ & M & $6-11$ & M & $6-11$ & M & $6-11$ & M & $6-11$ \\
\hline ROWC & 11 & ROWC & 11 & ROWC & 11 & ROWC & 11 & ROWC & 11 \\
\hline W & $11-13$ & W & $11-13$ & W & $11-13$ & W & $11-13$ & W & $11-13$ \\
\hline M & $14-21$ & $M$ & $14-21$ & $M$ & $14-21$ & $M$ & $14-21$ & $M$ & $14-21$ \\
\hline ROBL & 21 & ROBL & 21 & ROBL & 21 & ROBL & 21 & $\mathrm{ROBL}$ & 21 \\
\hline W & $21-23$ & W & $21-23$ & W & $21-23$ & W & $21-23$ & W & $21-23$ \\
\hline M & $24-31$ & M & $24-31$ & $M$ & $24-31$ & $M$ & $24-31$ & M & $24-31$ \\
\hline ROWC & 31 & ROWC & 31 & ROWC & 31 & RRC2AL & 31 & $\mathrm{RRC} 2 \mathrm{AL}$ & 31 \\
\hline W & $31-33$ & W & $31-33$ & W & $31-33$ & W & $31-35$ & W & $31-35$ \\
\hline$M$ & $34-40$ & $M$ & $34-40$ & $M$ & $34-40$ & $M$ & $36-40$ & $M$ & $36-40$ \\
\hline \multicolumn{10}{|c|}{ End of life 40 years } \\
\hline
\end{tabular}

Note: IC - initial construction; W - warranty period; M - maintenance period; ROWC replacement of the wearing course; ROBL - replacement of bituminous layers; RC2AL recycling + CBGM + two asphalt layers; RRC2AL - removal + recycling + CBGM + two asphalt layers. 
(M\&R) plans are based on initial constructions. Alternatives $A, B$, and $C$ include full-depth removal and replacement. These pavements differ in RA content (B alternative) and in wearing course thickness (C alternative). Full-depth removal and replacement involve activities such as demolition and transportation of old pavement to the lawful place.

For alternative $\mathrm{D}$ and $\mathrm{E}$ old pavement treatment by cement and fly ash was designed. When cement is used there always is a risk for fatigue and shrinkage cracks to develop. Another risk is unstable soil under the pavement cracking. It was assumed that cement and fly ash work similar. Therefore, a re-stabilization of the base is scheduled as a third rehabilitation for both alternatives D and E. It was assumed that for initial construction removal of old pavement is not planned and the old pavement is designed to be used as a lower base layer (treated by cement).

All pavement rehabilitation plans were made in cooperation with local experts because there was a lack of data from the road network. Also, they were made very similar for a more objective comparison.

\section{Results and discussion}

\subsection{Life Cycle Impact Assessment}

Life Cycle Impact Assessment (LCIA) was performed for all five alternatives. The results are shown in Figure 2. Demolition section includes old pavement removal and milling in every rehabilitation. Construction section includes initial construction and every rehabilitation. The results show that over 40 years, a full-depth reclamation technique (stabilization of the old pavement) produces on average $60 \%$ less $\mathrm{CO}_{2}$ in comparison to full-depth removal and replacement. Initial construction of alternatives $\mathrm{A}, \mathrm{B}$ and $\mathrm{C}$ produces more than two times more $\mathrm{CO}_{2}$ than alternatives $\mathrm{D}$ and $\mathrm{E}$. Besides, this calculation does not consider the extraction of raw materials from quarries and refineries. It means that the difference would be even more significant because, in alternatives A, B and C approximately four times more virgin mineral material is used than in alternatives $\mathrm{D}$ and E. Similarly, removal and transportation of old materials to the lawful place generates much waste as well produces three times more $\mathrm{CO}_{2}$ emissions.

The results show that alternatives $\mathrm{A}$ and $\mathrm{B}$ generates the same amount of $\mathrm{CO}_{2}$ emissions. That is so because the extraction of mineral materials and oil refining are excluded from the calculation.
Life Cycle Cost

Analysis and Life

Cycle Assessment for Road Pavement

Materials

and Reconstruction

Technologies 


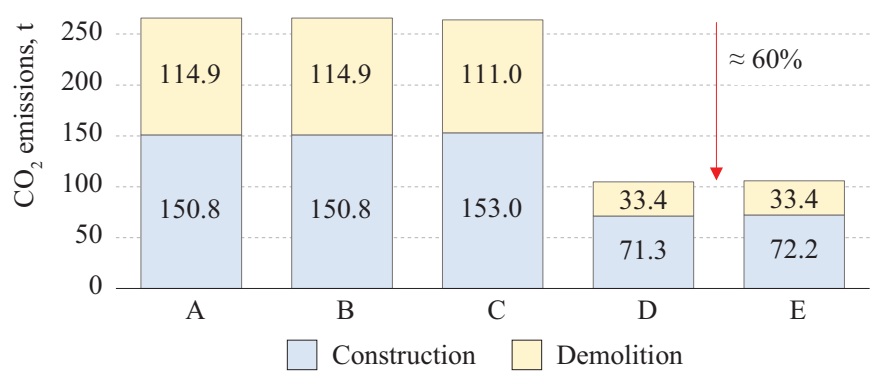

Figure 2. Amount of $\mathrm{CO}_{2}$ emissions for all five alternatives in the 40-year period

Alternative $\mathrm{C}$, which uses a BBTM wearing course, shows only a $1 \%$ reduction in $\mathrm{CO}_{2}$ emissions in 40 years. The reason is that raw material extraction was not included in the calculation.

When comparing alternatives $\mathrm{D}$ and $\mathrm{E}$, the demolition process for both alternatives is identical. The difference is in the number of materials that are used in the construction. In option E, the use of fly ash reduces the necessary amount of cement, which is needed to stabilize the layer. Studies show that the safe ratio is as follows: $20 \%$ of fly ash equal to $1 \%$ of cement. It is so because fly ash reduces the number of virgin materials for CBGM layer. Fly ash works as a binder and as a filler, and it results in a 33\% reduction of cement consumption and a $20 \%$ reduction of the use of new aggregates. However, as shown in Figure 2, it is essential to evaluate the production of raw materials to assess the environmental impact of binder, as $\mathrm{CO}_{2}$ reduction does not appear during the demolition and construction phases among the alternatives.

\subsection{Life Cycle Cost Analysis}

\subsubsection{Deterministic approach}

Life Cycle Cost Analysis (LCCA) was performed for all five alternatives. The results of the deterministic approach show that in a 40-year period, a full-depth reclamation pavement reconstruction technology is approximately $50 \%$ cheaper than full depth removal and replacement technology (Figure 3). Figure 3 shows that the reduction is in 3 positions - workforce, materials, and fuel. The only position where there is no difference is maintenance because, for all alternatives, this position was assumed to be equal.

The comparison of alternatives $\mathrm{A}, \mathrm{B}$, and $\mathrm{C}$ shows that $\mathrm{A}$ and $\mathrm{C}$ almost cost the same (B is a little bit cheaper). For alternative B, there is a cost 


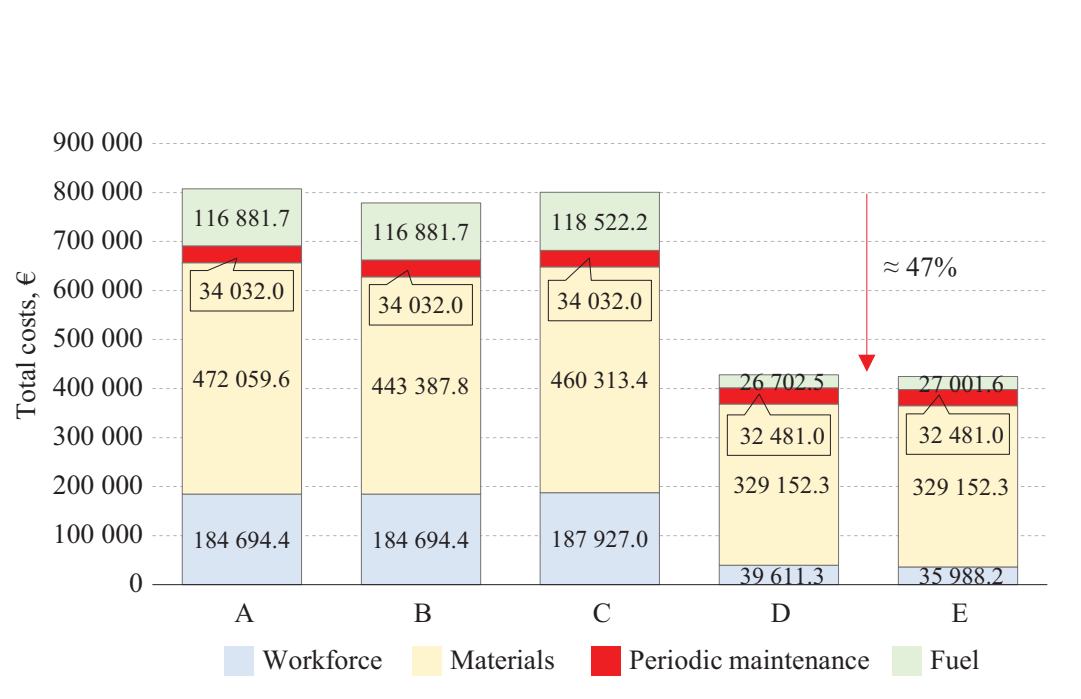

Figure 3. Results of Life Cycle Cost Analysis deterministic approach

reduction in material position, and it is logical because RA is used in asphalt layers. Alternative B is approximately $3.5 \%$ cheaper than option $\mathrm{A}$, and alternative $\mathrm{C}$ is almost $1 \%$ cheaper than $\mathrm{A}$.

The comparison between alternatives $\mathrm{D}$ and $\mathrm{E}$ shows that in case the fly ash is for free, it is possible to reduce the costs by $4 \%$ in a 40 -year period.

\subsubsection{Probabilistic approach}

Monte-Carlo simulations were done to draw probability distributions of expected costs for the whole life cycle. The theoretical normal distribution was used as a probability function. Twenty thousand iterations were generated for each alternative. The service life for each rehabilitation cycle was used as a variable. The average service life (mathematical expectation) was taken from Table 6 for each alternative. The longer the cycle was generated, the greater the uncertainty was assumed.

The obtained probability distributions with step 10000 EUR are shown in Figure 4. For alternatives A, B and C, where initial construction costs are higher, distribution of the results is closer to the normal distribution, and it means that it is possible to predict the costs with greater confidence. On the other hand, alternatives, D and E are showing a wider variation, which means that costs are harder to predict. Alternatives D and E tend to have two peaks. That is why it is hard to describe the distribution with one, but probably it is necessary to have two theoretical probability distributions. The reason why there is a tendency for two peaks for alternatives $\mathrm{D}$ and $\mathrm{E}$ is that as a third pavement reconstruction process the full depth reclamation 

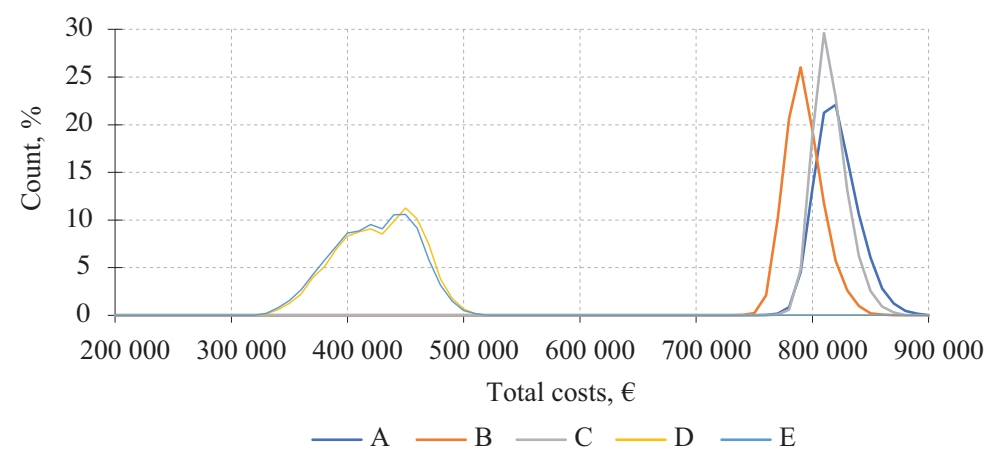

Figure 4. The probability distribution of costs for each alternative

is planned and it rises the costs and makes a peak in distribution (Table 6).

Confidence intervals with a 95\% probability were generated. Figure 5 shows the probability that road pavement costs in the 40 -year period are going to be within these limits. The results of the probabilistic approach show similar tendencies as in the deterministic approach - alternatives $\mathrm{D}$ and $\mathrm{E}$ are cheaper than $\mathrm{A}, \mathrm{B}$, and C.

The main difference in this approach is a range of intervals. Ranges for alternatives A, B, and C are smaller than for D and E. For alternative $\mathrm{C}$ it is the smallest one. For alternatives, D and E uncertainty about the costs are the highest. However, even at the worst scenario alternatives $D$ and $\mathrm{E}$ are less expensive than $\mathrm{A}, \mathrm{B}$ and $\mathrm{C}$.

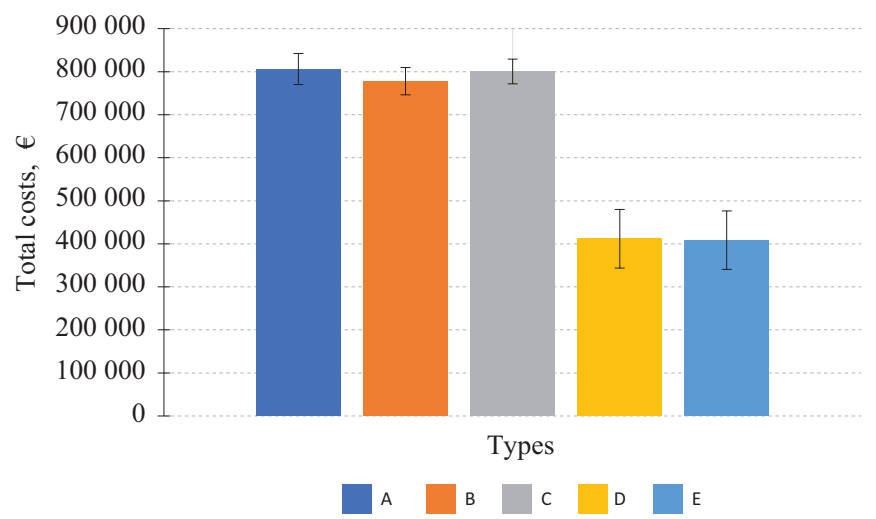

Figure $5.95 \%$ confidence interval costs are within these limits 


\section{Conclusions}

Full-depth reclamation technology has a lower carbon footprint than the full-depth removal and replacement technology conforming to the results. The difference in $\mathrm{CO}_{2}$ emissions in 40-year period is approximately $60 \%$ and would be even higher in case the raw material extraction was included in the calculation. The comparison of alternatives $\mathrm{A}, \mathrm{B}$ and $\mathrm{C}$ do not show the real difference as it does not calculate results from the raw material extraction. The same is with alternatives $\mathrm{D}$, and E. In real conditions alternative $\mathrm{E}$ in comparison to $\mathrm{D}$ generates less $\mathrm{CO}_{2}$ because of the reduction of cement and mineral materials.

The full-depth reclamation technology is cheaper than the fulldepth removal and replacement technology in 40-year period. The deterministic approach shows that alternative $\mathrm{A}$ is the most expensive and alternative $\mathrm{E}$ is the cheapest one. The variation of the results for alternatives $\mathrm{A}, \mathrm{B}$ and $\mathrm{C}$ are lower than for $\mathrm{D}$ and $\mathrm{E}$ because initial construction costs are much higher for the first three alternatives. In case the future costs are relatively high, the distribution of the costs in the whole calculation period is also great.

It is essential to choose an appropriate discount rate. For this study, a $4 \%$ discount rate was chosen. For future study, the influence of the various discount rate values is going to be evaluated.

The results show that the full depth reclamation technology (alternatives D and E) is more sustainable technology (than full-depth removal and replacement) that reduce $\mathrm{CO}_{2}$ emissions for at least $60 \%$ and reduce costs for at least $50 \%$. What is more, the use of fly ash reduces emissions because of the cement and aggregate reduction. The same as in the previous study of authors of this paper, wearing course of thin asphalt is more sustainable than conventional asphalt. The best combination of asphalt pavement surfacing materials is recycled asphalt in all asphalt layers with thin asphalt wearing course.

To fully evaluate the life cycle results of pavement from an environmental standpoint, it is necessary to include all stages and processes of the pavement life cycle. On the other hand, Life Cycle Cost Analysis could be done even when not all activities and processes from life cycle stages are taken in an account.

\section{Acknowledgements}

This study was co-financed by the European Regional Development (ERDF). Measure 1.1.1.1 "Industry-Driven Research" of specific objective 1.1.1 "To increase the research and innovation capacity of scientific institutions of Latvia and their ability to attract external funding by
Life Cycle Cost Analysis and Life Cycle Assessment for Road Pavement Materials and Reconstruction Technologies 
investing in human resources and infrastructure" within the project: No. 1.1.1.1/16/A/148 "Innovative use of reclaimed asphalt pavement for sustainable road construction layers".

Many thanks to Valters Abolins for developing the script of the calculation program.

Many thanks to SJSC Latvian State Roads, SIA Binders, ACB group, YIT Latvia for sharing the knowledge and for cooperation in data collection.

\section{Funding}

This study was co-financed by the European Regional Development (ERDF). Measure 1.1.1.1 "Industry-Driven Research" of specific objective 1.1.1 "To increase the research and innovation capacity of scientific institutions of Latvia and their ability to attract external funding by investing in human resources and infrastructure" within the project: No. 1.1.1.1/16/A/148 "Innovative use of reclaimed asphalt pavement for sustainable road construction layers".

\section{REFERENCES}

Babashamsi, P., Yusoff, N. I. M., Ceylan, H., Nor, N. G. M., \& Jenatabadi, H. S. (2016). Evaluation of pavement life cycle cost analysis: Review and analysis. International Journal of Pavement Research \& Technology, 9(4), 241-254. https://doi.org/10.1016/j.ijprt.2016.08.004

Brundtland Commission (1987). Our common future, Chapter 2: towards sustainable development. World Commission on Environment \& Development (WCED). Geneva: United Nation.

Chen, J. S., Yang, C. H., \& Lee, C. T. (2019). Field evaluation of porous asphalt course for life-cycle cost analysis. Construction \& Building Materials, 221, 20-26. https://doi.org/10.1016/j.conbuildmat.2019.06.072

Chen, X., \& Wang, H. (2018). Life cycle assessment of asphalt pavement recycling for greenhouse gas emission with temporal aspect. Journal of Cleaner Production, 187, 148-157. https://doi.org/10.1016/j.jclepro.2018.03.207

Demos, G. P. (2006). Life cycle cost analysis and discount rate on pavements for the Colorado Dept of Transportation (No. CDOT-2006-17).

Fontaras, G., Zacharof, N. G., \& Ciuffo, B. (2017). Fuel consumption and C02 emissions from passenger cars in Europe-laboratory versus real-world emissions. Progress in Energy \& Combustion Science, 60, 97-131. https://doi.org/10.1016/j.pecs.2016.12.004

ISO 14040:2006 Environmental Management - Life Cycle Assessment - Principles and Framework 
Kragh, J., Nielsen, E., Olesen, E., Goubert, L., Vansteenkiste, S., de Visscher, J., ..., \& Karlsson, R. (2011, March). Optimization of thin asphalt layers, OPTHINAL. Final report.

Li, J., Xiao, F., Zhang, L., \& Amirkhanian, S. N. (2019). Life cycle assessment and life cycle cost analysis of recycled solid waste materials in highway pavement: a review. Journal of Cleaner Production, 233, 1182-1206. https://doi.org/10.1016/j.jclepro.2019.06.061

Lima, M. S. S., Thives, L. P., \& Haritonovs, V. (2017). Rutting performance of bituminous mixtures composed with red mud. In Proc. of the $10^{\text {th }}$ International Conference on the Bearing Capacity of Roads, Railways \& Airfields, BCRRA 2017, (February), 349-355. https://doi.org/10.1201/9781315100333-51

Ma, H., Zhang, Z., Zhao, X., \& Wu, S. (2019). A Comparative Life Cycle Assessment (LCA) of Warm Mix Asphalt (WMA) and Hot Mix Asphalt (HMA) Pavement: a Case Study in China. Advances in Civil Engineering, 2019. https://doi.org/10.1155/2019/9391857

Ramadan, K. Z., \& Ashteyat, A. M. (2009). Utilization of white cement bypass dust as filler in asphalt concrete mixtures. Canadian Journal of Civil Engineering, 36(2), 191-195. https://doi.org/10.1139/108-124

Riekstins, A., Haritonovs, V., Abolins, V., Straupe, V., \& Tihonovs, J. (2019). Life cycle cost analysis of BBTM and traditional asphalt concretes in Latvia. Engineering for Rural Development, 18(May), 1065-1072. https://doi.org/10.22616/ERDev2019.18.N400

Santero, N., Masanet, E., \& Horvath, A. (2010). Life Cycle Assessment of Pavements: a Critical Review of Existing Literature and Research. Lawrence Berkeley National Laboratory, (April), 81. https://doi.org/10.1016/j.resconrec.2011.03.010

Santos, J., Flintsch, G., \& Ferreira, A. (2017). Environmental and economic assessment of pavement construction and management practices for enhancing pavement sustainability. Resources, Conservation \& Recycling, 116, 15-31. https://doi.org/10.1016/j.resconrec.2016.08.025

Santos, J., Thyagarajan, S., Keijzer, E., Flores, R., \& Flintsch, G. (2017, April). Pavement life cycle assessment: a comparison of American and European tools. In Proc. of the Pavement Life-Cycle Assessment Symposium, 2017, 1-10. https://doi.org/10.1201/9781315159324-2

Shukla, N., \& Jani, H. J. (2018). Social Impact Assessment of Road Infrastructure Projects, Global Journal of Commerce \& Management Perspective, 7(1), 53-73.

SJSC Latvian State Roads (2019). Nestingās ceḷa segas aprēķina sistēma (in Latvian)

Vestin, J., Arm, M., Nordmark, D., Lagerkvist, A., Hallgren, P., \& Lind, B. (2012, May). Fly ash as a road construction material. In WASCON 2012 Conference proceedings, ISCOWA \& SGI.

Walls, J., \& Smith, M. R. (1998). Life-cycle cost analysis in pavement design: interim technical bulletin (No. FHWA-SA-98-079). The United States. Federal Highway Administration. 